evinced by Hill towards Collins, therefore I decided to defer publication until someone confirmed it, which has been done by a member of the Geological Survey of Malaya, Mr. F. H. Fitch who was stationed in Kuantan and is now in England. He tells me there is no doubt of the sequence and that he has seen xenoliths of dolerite in a quartz-porphyry dyke. It does not follow of course that because a certain sequence of igneous rocks has been proved in Malaya a similar sequence must be accepted for Cornwall, roughly 8,000 miles away, without evidence equally clear ; but it must be conceded that Collins, who unfortunately was sometimes vague in differentiating between igneous rocks, may have been quite correct when he described a mica-trap as being intersected by a felspar-porphyry, and that he and Hill were right in considering the elvans later than the mica-traps.

Collins, J. H., 1884. The Geological Age of Central and West Cornwall. Journ. Royal Inst. Cornwall, viii, 162-205.

Hill, J. B., 1901. The Plutonic and other Intrusive Rocks of West Cornwall and their relation to the mineral ores. Trans. Royal Geol. Soc. Cornwall, xii, pt. vii.

1906. The Geology of Falmouth and Truro, etc. Mem. Geol. Surv. Great Britain. (Explanation of Sheet 352.)

SCrivenor, J. B., 1931. The Geology of Malaya. London.

Ussher, W. A. E., and J. J. H. Teall, 1902. The Geology of the Country Round Exeter. Mem. Geol. Surv. Great Britain. (Explanation of Sheet 325.)

VerSEY, H. C., 1929. Chapter 7 (Permian) in Handbook of the Geology of Great Britain, edited by J. W. Evans and C. J. Stubblefield. London.

68 Chaucer Road, J. B. Scrivenor.

BEDFORD.

20th May, 1946.

\title{
THE CONCENTRATION OF MANGANESE ORES
}

SIR,--In his Bulletin (1943) on the Geology of the Nsuta manganese ore deposits Mr. H. Service has shed much light on an occurrence whose economic importance has been no less than its scientific interest for some thirty years. The deeper working of the deposits appears to have demonstrated an original - or at any rate a geologically ancient-concentration of manganese ore in the Birrimian rocks. It is of interest to notice the similarity between the Birrimian rocks of Nsuta and those of Tassawini, Barama River, British Guiana, where a deposit of manganese ore has been described by Dr:D. A. Bryn-Davies.

The authors of an earlier paper (1930) were mainly concerned in 1926 with the superficially enriched ore which was then the principal product of the Nsuta mines. In suggesting that the importance of meteoric weather was overstressed by Bishopp and Hughes, Mr. Service has surely overlooked one of our more important arguments and does not appear to have adduced it in his own paper. I refer to the widespread occurrence and weathering of pyrites in the Birrimian rocks. We recorded the mineral in basic carbonate-talc-chlorite schist, as well as in the intrusive felspar-porphyries which are closely associated with the manganese orebodies; Service mentions its presence in the "Green Schists" and phyllites (pp. 13 and 14 of his work). 
Sulphuric acid seems to be of special importance in the solution and redistribution of manganese. For example, sulphate of manganese solution is hydrolyzed so rapidly in the soil that it is sprayed on to the foliage of plants suffering from manganese deficiency, instead of being applied at the root. A little sulphuric acid should accordingly produce a relatively large effect in a manganese deposit, for it will go on reacting until fixed by some more stable base. There is thus no prima facie objection to the formation of ore of high purity from a very low grade primary phyllite with a manganese content of the order of 1 per cent (Service, 1943, p. 9 ; Bishopp and Hughes, 1930, p. 167).

This of course does not traverse Service's inference that the principal ore-bodies at Nsuta existed in pre-Devonian time; the question is how far these have been reconcentrated by hydrothermal agencies as well as by later meteoric action. Developing the suggestion made by R. H. Rastall (1944), it would seem possible that sulphuric acid may play as important a part in the secondary oxide enrichment of manganese as it does in the secondary sulphide concentration of copper.

\section{REFERENCES}

Bishopp, D. W., and Hughes, W. J., 1930. Trans. Inst. Min. Met. London, xxxix, 142-191.

Bryn-Davies, D. A., 1937-8. Geol. Survey British Guiana, Bull. No. 14, Georgetown, 1940 .

Service, H., 1943. Gold Coast Geological Survey, Memoir No. 5.

Rastall, R. H., 1944. Rainfall, Rivers, and Erosion. Geol. Mag., lxxxi, 39-44.

Geological Survey Office,

D. W. Bishopp.

14 Hume STREeT,

DuBLIN.

11 th April, 1946.

\section{REVIEWS}

Petrological Studies on some Basaltic Rocks from East Greenland. By T. KRокSTRöм. Meddelelser om Grönland, Band 103, No. 6, pp. 73, with 2 plates and 5 figures, 1944.

This memoir contains a detailed description of some rock specimens from the Scoresby Sound region collected during Dr. Lauge Koch's expeditions between 1929 and 1934, and it includes an appendix by Professor Backlund on their field relations.

In the petrographical descriptions they are classed as olivine-dolerites, plagioclase-porphyrites and basalts, but it is explained that the dolerites and basalts are really the same, differing only in texture. The field relations of the two main groups are imperfectly known, but according to Professor Backlund a dolerite dyke has been seen cutting a porphyrite. An older complex of alnöitic lamprophyres is not here described.

A most elaborate and careful description is given of all the constituent minerals, and some analyses, due to Dr. Sahlbom, are subjected to every form of calculation, such as is now so fashionable in petrography: norms, molecular proportions, Niggli numbers, and the rest of it. In 